\title{
Neurotransmitter Coupling through Gap Junctions in the Retina
}

\author{
David I. Vaney, J. Charles Nelson, and David V. Pow \\ Vision, Touch and Hearing Research Centre, Department of Physiology and Pharmacology, The University of Queensland, \\ Brisbane 4072, Australia
}

Although all bipolar cells in the retina probably use the excitatory transmitter glutamate, approximately half of the cone bipolar cells also contain elevated levels of the inhibitory transmitter glycine. Some types of cone bipolar cells make heterologous gap junctions with rod amacrine cells, which contain elevated levels of glycine, leading to the hypothesis that the bipolar cells obtain their glycine from amacrine cells. Experimental support for this hypothesis is now provided by three independent lines of evidence. First, the glycine transporter GLYT1 is expressed by the glycine-containing amacrine cells but not by the glycine-containing bipolar cells, suggesting that only the amacrine cells are functionally glycinergic. Second, the gap-junction blocker carbenoxolone greatly reduces exogenous ${ }^{3} \mathrm{H}$-glycine accumulation into the bipolar cells but not the amacrine cells. Moreover, when the endogenous glycine stores in both cell classes are depleted by incubating the retina with a glycine-uptake inhibitor, carbenoxolone blocks the subsequent glycine replenishment of the bipolar cells but not the amacrine cells. Third, intracellular injection of rod amacrine cells with the gap-junction permeant tracer Neurobiotin secondarily labels a heterogenous population of cone bipolar cells, all of which show glycine immunoreactivity. Taken together, these findings indicate that the elevated glycine in cone bipolar cells is not derived by high-affinity uptake or de novo synthesis but is obtained by neurotransmitter coupling through gap junctions with glycinergic amacrine cells. Thus transmitter content may be an unreliable indicator of transmitter function for neurons that make heterologous gap junctions.

Key words: gap junction; neurotransmitter coupling; glycine; glycine transporter; GLYT1; retina; amacrine cell; bipolar cell; tracer coupling; Neurobiotin; carbenoxolone; sarcosine
Gap junctions between neurons serve two distinct functions (for review, see Spray, 1996). First, gap junctions are readily permeable to small ions and thus function as electrical synapses, allowing current carried largely by potassium ions to pass directly between neurons. Second, gap junctions are also permeable to metabolites with molecular weights below $\sim 1000$ Da. Such metabolic coupling is dependent on molecules diffusing down a concentration gradient, whereas electrical coupling is dependent on ions moving down a potential gradient. It has been shown that gap junctions in various systems are permeable to amino acids (Rieske et al., 1975; Finbow and Pitts, 1981; Brissette et al., 1994) and to many second-messenger molecules, including cyclic nucleotides, inositol triphosphate, and calcium ions (Tsien and Weingart, 1976; Brehm et al., 1989; Sáez et al., 1989; Kandler and Katz, 1998). The amino acid transmitters glycine (75 Da), $\gamma$-aminobutyric acid (103 Da), and glutamate (147 Da) should pass readily through neuronal gap junctions, but there is no experimental evidence that neurotransmitter coupling occurs naturally in the nervous system.

In the mammalian retina, the extensive gap junctions between the rod (AII) amacrine cells and cone bipolar cells (Kolb and Famiglietti, 1974) potentially provide a pathway for neurotransmitter coupling. Stimulation of the rod photoreceptors leads to depolarization of the AII amacrine cells, and this response is transmitted electrically through the heterologous gap junctions

\footnotetext{
Received Aug. 26, 1998; revised Sept. 25, 1998; accepted Sept. 30, 1998.

This work was supported by the National Health and Medical Research Council (Australia)

Correspondence should be addressed to Dr. D. I. Vaney, Vision, Touch and Hearing Research Centre, Department of Physiology and Pharmacology, The University of Queensland, Brisbane 4072, Australia.

Copyright (C) 1998 Society for Neuroscience $\quad 0270-6474 / 98 / 1810594-09 \$ 05.00 / 0$
}

into depolarizing cone bipolar cells, which then convey the rod signal to the retinal ganglion cells (for review, see Vaney, 1997). The AII amacrine cells appear to be functionally glycinergic in that (1) they contain elevated levels of glycine but negligible amounts of $\gamma$-aminobutyric acid (Pourcho and Goebel, 1987b; Wright et al., 1997), (2) their chemical transmission is blocked by the glycinergic antagonist strychnine (Müller et al., 1988), and (3) their output synapses are immunoreactive for the $\alpha 1$ subunit of the glycine receptor (Sassoè-Pognetto et al., 1994). Although it appears that all bipolar cells in the retina use the excitatory transmitter glutamate (for review, see Massey, 1990), approximately half of the cone bipolar cells also contain and accumulate elevated levels of the inhibitory transmitter glycine (for review, see Pourcho and Goebel, 1990). It has been proposed that the glycine in the AII amacrine cells diffuses through the heterologous gap junctions into the cone bipolar cells (Marc, 1984, 1989; Cohen and Sterling, 1986; for review, see Vaney, 1994).

We have tested this hypothesis from three independent perspectives. First, we examined whether the glycine-containing bipolar cells express the high-affinity glycine transporter GLYT1. Second, we determined whether gap-junction blockers affect the accumulation of glycine by the bipolar cells, both exogenously and after depletion of the endogenous glycine stores. Third, we verified directly that the bipolar cells coupled to the AII amacrine cells contain elevated levels of glycine.

\section{MATERIALS AND METHODS}

All experiments were approved by the University of Queensland animal experimentation ethics committee and were conducted in accord with the Australian code of practice for the care and use of animals for scientific purposes. Adult pigmented rabbits and Dark Agouti rats were obtained from the University of Queensland Central Animal House. Biochemical 
reagents were obtained from Sigma (St. Louis, MO) unless indicated otherwise.

Immunocytochemistry. The GLYT1 antigen was a synthetic peptide (Auspep, Melbourne, Australia) corresponding to the final 15 amino acids in the $\mathrm{C}$ terminus, which is common to both splice variants (GLYT1a and GLYT1b) (Liu et al., 1993). The peptide (2 mg) was coupled to porcine thyroglobulin $(20 \mathrm{mg})$ using formaldehyde, and a guinea pig was immunized by our standard techniques (Pow and Crook, 1993). Specificity was initially assessed by Western blotting using homogenates of retina and spinal cord. This revealed a single immunoreactive band with a molecular weight of $\sim 68 \mathrm{kDa}$, corresponding to the predicted molecular weight of GLYT1 (Zafra et al., 1995). Dot blots using the synthetic peptide coupled to bovine serum albumin demonstrated that the antiserum recognized formaldehyde conjugates of the peptide, and that this labeling was abolished after preabsorption of the antiserum with the peptide conjugate used for immunization. The rat antiserum against a formaldehyde conjugate of glycine has been characterized previously (Pow et al., 1995). Formaldehyde-fixed retinal whole mounts and vibratome sections were double-labeled for GLYT1- and glycineimmunofluorescence, as described elsewhere (Pow et al., 1995; Wright et al., 1997). Images of the preparations were acquired with a Bio-Rad MRC 600 confocal microscope, analyzed using NIH Image 1.62, and prepared for publication using Adobe Photoshop 4. In most cases, digital processing was confined to adjusting the origin and slope of the linear input-output curve, thus manipulating the brightness and contrast of the image. In Figure 5, the variations command of Photoshop was used to add red (or green) to the midtones and shadows, and to add cyan (or magenta) to the highlights.

Tracer-coupling experiments. The detailed procedures have been described elsewhere (Vaney, 1991; Hampson et al., 1992; Wright et al., 1997) for preparing the superfused whole mounts of the rabbit retina, for intracellular injection of microscopically identified cells with Neurobiotin (Vector, Burlingame, CA), and for visualizing the tracer-coupled neurons in combination with glycine-immunofluorescence. The retina was metachromatically labeled with Nuclear Yellow (Hoechst, Frankfurt, Germany), enabling the AII amacrine cells to be distinguished from other amacrine cells by their bright yellow fluorescence (Vaney et al., 1991).

Glycine-accumulation experiments. The effects of the gap-junction blocker carbenoxolone on the pattern of ${ }^{3} \mathrm{H}$-glycine uptake were examined in rabbit eyecup preparations. Pieces of tissue were incubated for 60 min at $35^{\circ} \mathrm{C}$ in serum-free Ames medium ( $6 \mu \mathrm{M}$ glycine $)$, with or without $50 \mu \mathrm{M}$ carbenoxolone, and then incubated for $15 \mathrm{~min}$ in $1.0 \mathrm{ml}$ of the same solution containing $50 \mu \mathrm{l}$ of ${ }^{3} \mathrm{H}$-glycine $(16.2 \mathrm{Ci} / \mathrm{mM}$; TRK71, Amersham, Little Chalfont, England), giving a final glycine concentration of $9 \mu \mathrm{M}$. After a brief wash, the eyecup was fixed in $4 \%$ paraformaldehyde and $0.2 \%$ glutaraldehyde in phosphate buffer for $90 \mathrm{~min}$ at $4{ }^{\circ} \mathrm{C}$, and the tissue was then processed for autoradiography, as described elsewhere (Wright et al., 1997).

Glycine-depletion experiments. Isolated rat retinas were incubated for $3 \mathrm{~h}$ at $35^{\circ} \mathrm{C}$ in serum-free Ames medium containing $0.5 \mathrm{~mm}$ sarcosine to deplete the endogenous glycine in the amacrine cells and the bipolar cells (Pow, 1998). The pattern of glycine replenishment was then examined in retinas that were incubated in normal Ames medium, in the presence or absence of the gap-junction blocker (50 $\mu \mathrm{M}$ carbenoxolone). The experimental protocols are outlined in the legend of Figure 4. Vibratome sections of the retinas were processed for glycine-immunofluorescence using a standardized protocol.

\section{RESULTS}

\section{Cellular localization of the glycine transporter}

The identification of the neurotransmitter used by a particular neuron is commonly made on the basis of transmitter content, but this is greatly strengthened by the cellular localization of both a synthetic pathway and a re-uptake pathway for the putative transmitter. Although glycine is synthesized by diverse metabolic pathways, it has generally been assumed that glycine synthesis in the CNS is largely mediated by serine-hydroxymethyl transferase, using serine and tetrahydrofolic acid as substrates (Daley, 1990). However, a recent study on the retina indicated that the elevated levels of glycine in amacrine cells and bipolar cells depend primarily on glycine uptake, with only a few amacrine cells showing the capacity to synthesize glycine (Pow, 1998). Under these circumstances, the cellular localization of a highaffinity glycine transporter assumes special importance in identifying glycinergic neurons. For most neurons, the presence of a glycine transporter can be inferred from the high-affinity uptake of radiolabeled glycine. However, this does not hold for the glycine-accumulating cone bipolar cells, which could obtain the exogenous glycine indirectly via the glycine-accumulating AII amacrine cells (or vice versa).

In the rabbit retina, the immunocytochemical localization of the high-affinity glycine transporter GLYT1 resulted in specific labeling of the plasma membranes of $\sim 60 \%$ of the neurons located at the inner margin of the inner nuclear layer (the amacrine sublayer). The GLYT1-immunoreactive cells branched only in the inner plexiform layer, confirming that they were amacrine cells, in agreement with an earlier study on the rat retina (Zafra et al., 1995). Whole mounts and transverse sections were doublelabeled for GLYT1- and glycine-immunofluorescence, which were visualized sequentially under a high-power objective using fluorescence filter sets that were selective for FITC or Texas Red. This revealed that most of the glycine-containing cells in the amacrine sublayer expressed GLYT1, although the levels of immunofluorescence varied widely (Fig. $1 A-D$ ). Consequently, the GLYT1-immunofluorescence can be difficult to detect when the two fluorophores are visualized simultaneously, particularly in amacrine cells that show strong glycine-immunofluorescence (Fig. $1 E, F)$. In contrast to the colocalization of glycine and GLYT1 in the amacrine cells, none of the glycine-containing bipolar cells expressed detectable levels of GLYT1-immunofluorescence.

The AII amacrine cells in these preparations could be identified by morphological and neurochemical criteria: the large cell body protruded into the inner plexiform layer, giving rise to a stout primary dendrite that was encircled by a ruffle of lobular appendages (Kolb and Famiglietti, 1974; Vaney et al., 1991). Although the AII amacrine cells contained only moderate levels of glycine (Wright et al., 1997), all parts of the plasma membrane were strongly immunoreactive for GLYT1. A second high-affinity glycine transporter, GLYT2, is also expressed in the CNS, but it has not been detected in the retina by immunocytochemistry (Zafra et al., 1995).

Taken together, these observations indicate that the heterologous gap junctions between the AII amacrine cells and the cone bipolar cells may provide the only pathway for the bipolar cells to acquire extracellular glycine through high-affinity uptake. This was tested directly by examining the patterns of glycine accumulation when these gap junctions were blocked.

\section{Uncoupling of retinal neurons with carbenoxolone}

Each AII amacrine cell makes both homologous gap junctions with neighboring AII cells and heterologous gap junctions with underlying cone bipolar cells (Kolb and Famiglietti, 1974; for review, see Vaney, 1997). This complex pattern of connectivity can be visualized graphically by injecting a gap junction-permeant tracer into microscopically identified AII cells in a superfused preparation of the isolated rabbit retina (Vaney, 1991) (Fig. 2A). The somata of the tracer-coupled bipolar cells differ in their size, depth, labeling intensity, and calbindin immunoreactivity, indicating that they comprise several types of neurons (Hampson et al., 1992; Massey and Mills, 1996). The heterologous tracer coupling can be selectively reduced by nitric oxide and cGMP agonists, but it is not eliminated (Mills and Massey, 1995). We thus 


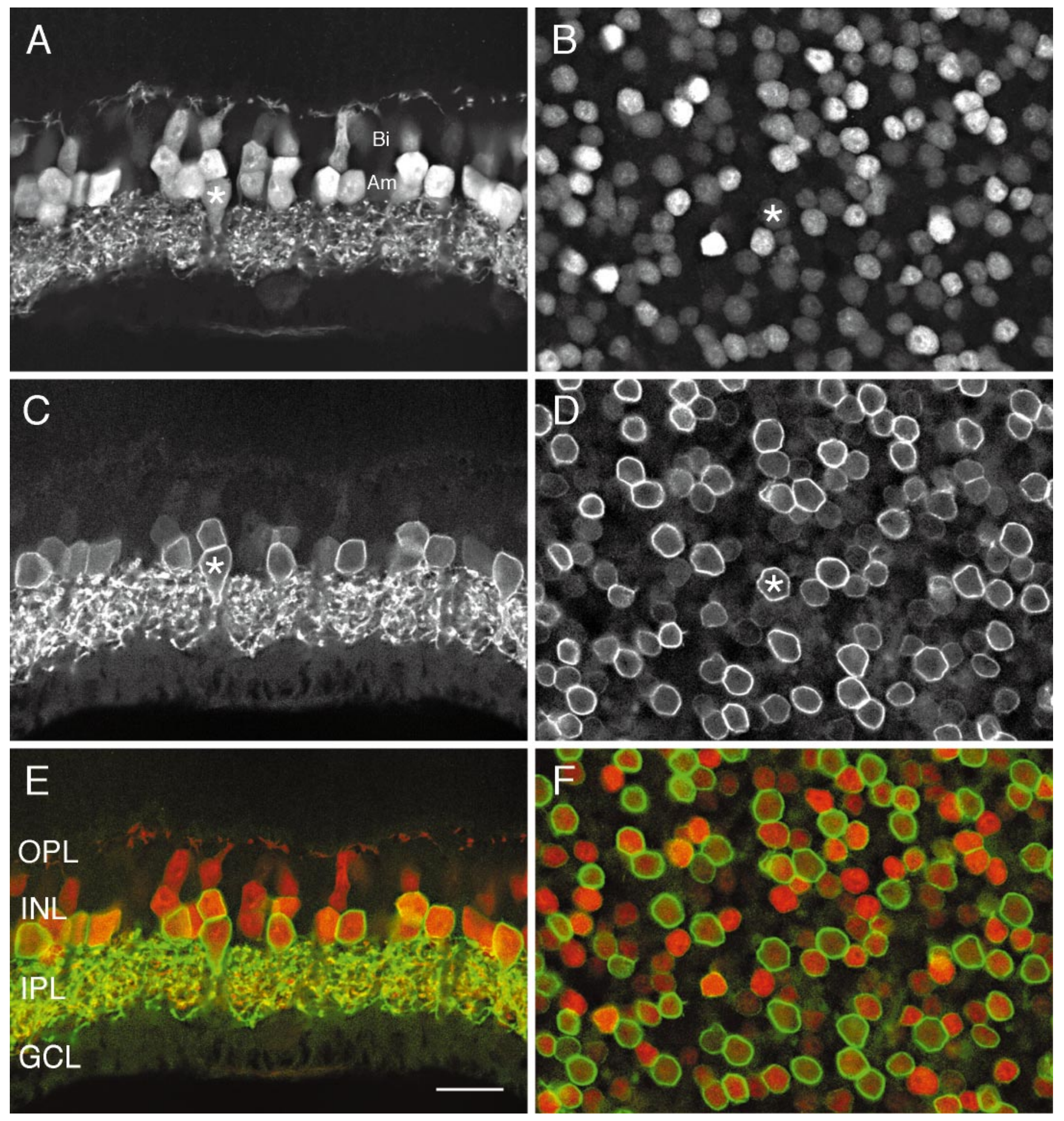

Figure 1. Immunocytochemical localization of glycine and GLYT1 in the retina. Confocal fluorescence micrographs of the rabbit retina immunolabeled for glycine $(A, B)$ and the glycine transporter GLYT1 $(C, D)$, as seen in a transverse vibratome section $(A, C, E)$, and a whole mount with the focus on the amacrine sublayer of the inner nuclear layer $(B, D, F)$. GLYT1 is expressed by the glycine-containing amacrine cells $(A m)$ but not by the glycine-containing bipolar cells $(B i)$. Asterisks mark representative AII amacrine cells, which show strong GLYT1 immunoreactivity in the plasma membrane but only moderate glycine immunoreactivity in the cytoplasm. $O P L$, Outer plexiform layer; $I N L$, inner nuclear layer; $I P L$, inner plexiform layer; GCL, ganglion cell layer. Scale bar, $20 \mu \mathrm{m}$.

tested the effects of various lipophilic molecules that have been shown to reduce gap-junctional intercellular communication in other systems.

Heptanol and octanol abolished the tracer coupling at low millimolar concentrations, but these commonly used alcohols are known to have nonspecific effects on other membrane channels. The tracer coupling was also abolished by two glycrrhetinic acid derivatives (Davidson and Baumgarten, 1988; Guan et al., 1996) 


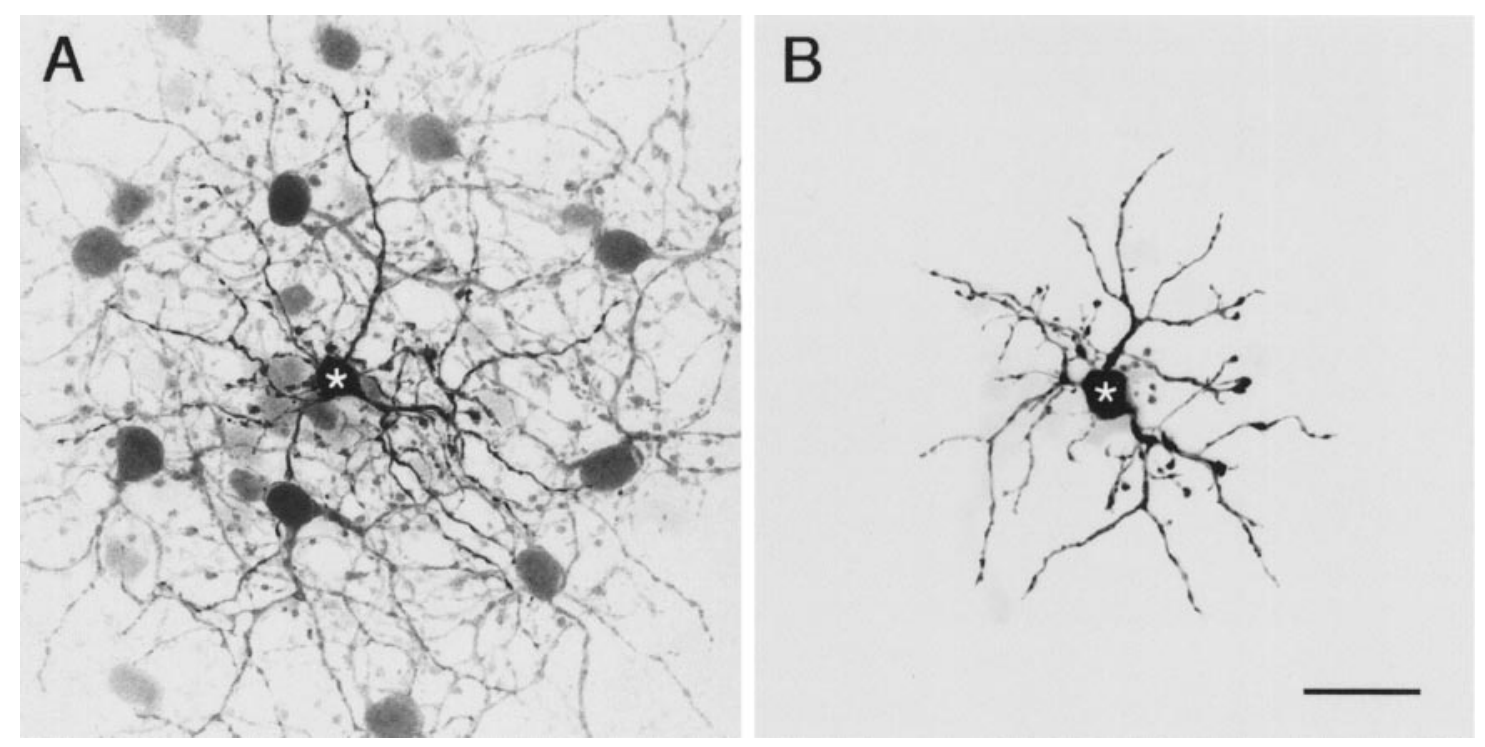

Figure 2. Coupling and uncoupling of AII amacrine cells. Negative images of Neurobiotin-injected AII cells (asterisks) in whole mounts of the rabbit retina, reconstructed from a Z-series of confocal micrographs. $A$, Under control conditions, injection of Neurobiotin into an AII amacrine cell results in homologous tracer coupling to neighboring AII cells and heterologous tracer coupling to underlying cone bipolar cells. $B$, When the retina is incubated with the gap-junction blocker carbenoxolone before injection, the tracer is confined to the injected AII amacrine cell. Scale bar, $20 \mu \mathrm{m}$.

used at micromolar concentrations: $25 \mu \mathrm{M}$ enoxolone was as effective as $50 \mu \mathrm{M}$ carbenoxolone, but prolonged incubation with enoxolone caused swelling of somata. Carbenoxolone, which is water soluble, was used as the uncoupling agent of choice in this study, because electrophysiological experiments on brain slices indicated that $30-100 \mu \mathrm{M}$ carbenoxolone had no effect on the cell conductance or the kinetics of stepped currents (Osborne and Williams, 1996). A 60 min incubation with $50 \mu \mathrm{M}$ carbenoxolone abolished the tracer coupling of AII amacrine cells, which was reversible after washout (Fig. $2 B$ ). At shorter times and/or lower concentrations, weak heterologous coupling sometimes persisted after the homologous coupling was eliminated, thus providing further evidence that the homologous and heterologous gap junctions of the AII amacrine cells differ in their functional properties (Mills and Massey, 1995; Vaney, 1997). The glycrrhetinic acid derivatives also abolished the extensive tracer coupling between the A-type horizontal cells but had little effect on the tracer coupling between the reciprocal rod (AI) amacrine cells.

\section{Patterns of glycine accumulation in coupled and uncoupled retinas}

Numerous autoradiographic studies [Ehinger and Falck (1971); for review, see Marc (1984); Pourcho and Goebel (1990)] have shown that a short exposure of the retina to a low concentration of radiolabeled glycine, either in vivo or in vitro, results in specific labeling of a subset of the amacrine cells and the bipolar cells. The normal pattern of glycine uptake was confirmed in this study, using pieces of rabbit retina incubated for 10-15 min in tissue culture medium containing ${ }^{3} \mathrm{H}$-glycine (Wright et al., 1997). Most of the glycine-accumulating amacrine cells, which were located at the inner margin of the inner nuclear layer, showed denser labeling than the glycine-accumulating bipolar cells, which were located more distally (Fig. 3A). When the gap junctions were blocked by incubating the retina with carbenoxolone, the bipolar cells showed greatly reduced autoradiographic labeling (Fig. $3 B$ ). This provided experimental evidence that the apparent uptake of ${ }^{3} \mathrm{H}$-glycine by the cone bipolar cells is deceptive. The exogenous glycine is probably accumulated by the amacrine cells and then diff uses into the bipolar cells through heterologous gap junctions.

A related experiment confirmed that the elevated levels of endogenous glycine in the cone bipolar cells actually arise from the intracellular stores in amacrine cells, rather than directly from extracellular sources. We took advantage of our recent finding (Pow, 1998) that the endogenous glycine in both amacrine cells and bipolar cells can be depleted dramatically by prolonged incubation of the retina with excess sarcosine (methylglycine) (Fig. 4A). Sarcosine is a potent inhibitor of the glycine transporter GLYT1 (Blasberg and Lajtha, 1966; Guastella et al., 1992), and thus prevents the re-uptake of glycine that is released from the amacrine cells. The effects of sarcosine were reversible after washout, leading to subsequent replenishment of the endogenous glycine stores in both amacrine cells and bipolar cells (Pow, 1998) (Fig. 4B). However, carbenoxolone blocked the glycine replenishment of the bipolar cells but not the amacrine cells (Fig. 4C). Thus the bipolar cells could not restore their elevated levels of endogenous glycine, by either uptake or synthesis, when the gap junctions were blocked. The sarcosine experiments were performed on the rat retina because sarcosine has complex effects on the rabbit retina. In addition to depleting the endogenous glycine in the amacrine and bipolar cells, sarcosine induces glycine uptake by one type of GABAergic amacrine cell in the rabbit retina, thus confounding the presentation of the sarcosine-carbenoxolone experiment (Pow and Vaney, 1998).

It might be expected that blocking the gap junctions before sarcosine incubation would trap the endogenous glycine in the bipolar cells, thus preventing its depletion. This was not the case, suggesting that the bipolar cells either release the glycine directly or convert it to another metabolite that is not detectable by glycine immunocytochemistry. Moreover, it is possible that the heterologous gap junctions between cone bipolar cells and AII amacrine cells are asymmetrically permeable to glycine, as appears to be the case with biotinylated tracers (for review, see Vaney, 1997). 
Figure 3. Uptake of exogenous glycine in coupled and uncoupled retinas. Autoradiographs of transverse plastic sections of the rabbit retina showing the pattern of ${ }^{3} \mathrm{H}$-glycine accumulation in vitro. $A$, Under control conditions, exogenous glycine is accumulated by subpopulations of both the amacrine cells $(A m)$ and the bipolar cells $(B i) . B$, When the retina is incubated with the gap-junction blocker carbenoxolone, exogenous glycine is accumulated by the amacrine cells $(\mathrm{Am})$ but not by the bipolar cells. Scale bar, $20 \mu \mathrm{m}$.
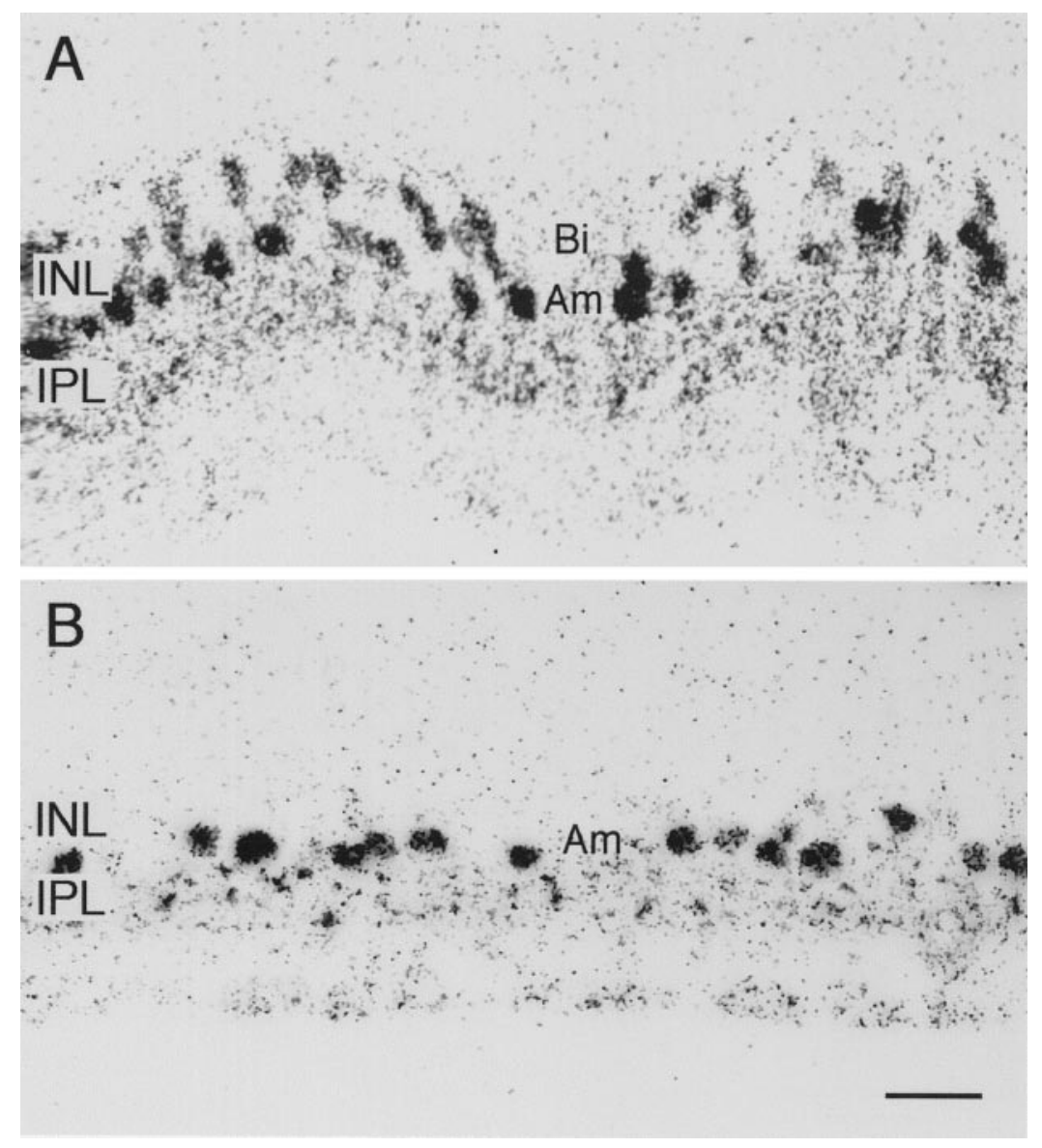

\section{Glycine immunoreactivity of tracer-coupled bipolar cells}

Using electron microscope autoradiography, Cohen and Sterling (1986) measured the levels of accumulated ${ }^{3} \mathrm{H}$-glycine in all cone bipolar (CB) somata located in a small patch of the cat retina. Approximately half of the cells showed light labeling, and their axons terminated proximally in sublamina $a$ of the inner plexiform layer ( $\mathrm{CB} a$ cells); most of the other cells showed moderate labeling, and their axons terminated distally in sublamina $b(\mathrm{CB} b$ cells). Almost all of the $\mathrm{CB} b$ cells were coupled by gap junctions to AII amacrine cells (Cohen and Sterling, 1990), either directly or indirectly, supporting the hypothesis that the radiolabeled bipolar cells obtained the ${ }^{3} \mathrm{H}$-glycine from the AII amacrine cells. However, another autoradiographic study (Pourcho and Goebel, 1987a) on cat retina indicated that two types of CBa cells show greater ${ }^{3} \mathrm{H}$-glycine accumulation than one type of $\mathrm{CB} b$ cell. Moreover, later immunocytochemical studies on cat retina (Pourcho and Goebel, 1987b) and primate retina (Hendrickson et al., 1988) indicated that a minority of the $\mathrm{CB} b$ cells are glycine immunonegative and that a minority of the $\mathrm{CB} a$ cells are glycine immunopositive. We therefore tested directly whether all of the bipolar cells that are coupled to AII amacrine cells show glycine immunoreactivity, and vice versa.

The coupled bipolar cells were labeled by injecting Neurobiotin into microscopically identified AII amacrine cells in the isolated rabbit retina and then visualizing the tracer-coupled neurons with Texas Red-tagged streptavidin. The preparations were also processed for glycine-immunofluorescence using an antiserum against a formaldehyde conjugate of glycine, which is effective on lightly fixed retinal whole mounts (Pow et al., 1995). The primary antibody was visualized with an FITC-tagged secondary antibody, enabling simultaneous visualization of the two fluorophores by confocal microscopy (Wright et al., 1997). More than 30 AII cells were injected with Neurobiotin, and in each case the tracer-coupled bipolar cells showed a consistent pattern of glycine immunoreactivity.

The injected AII amacrine cells showed both homologous tracer coupling to neighboring AII cells (Fig. $5 A$ ) and heterologous tracer coupling to underlying cone bipolar cells (Fig. $5 B$ ). The tracer-coupled AII cells, which showed moderate levels of glycine-immunofluorescence, accounted for $\sim 15 \%$ of the glycineimmunopositive somata in the amacrine sublayer of the inner nuclear layer (Wright et al., 1997) (Fig. 5C). Almost all of the tracer-coupled bipolar cells could also be discriminated immunocytochemically, indicating that these cells contained levels of endogenous glycine that were significantly greater than the metabolic pools present in all neurons (Fig. 5D).

Approximately $20 \%$ of the glycine-immunopositive cells in the bipolar sublayer appeared to show little if any tracer coupling. However, quantitative image analysis of such bipolar cells underlying the well filled AII amacrine cells in the center of the field revealed signal levels approximately twice that of the background Texas Red fluorescence. The tracer levels of these weakly coupled bipolar cells were $\sim 5 \%$ of the tracer levels of adjacent strongly coupled bipolar cells (after subtracting the background fluorescence). In the composite micrograph (Fig. 5F), the strongly coupled bipolar cells appear brown, whereas the other glycine-immunopositive cells appear green. Their regularly 

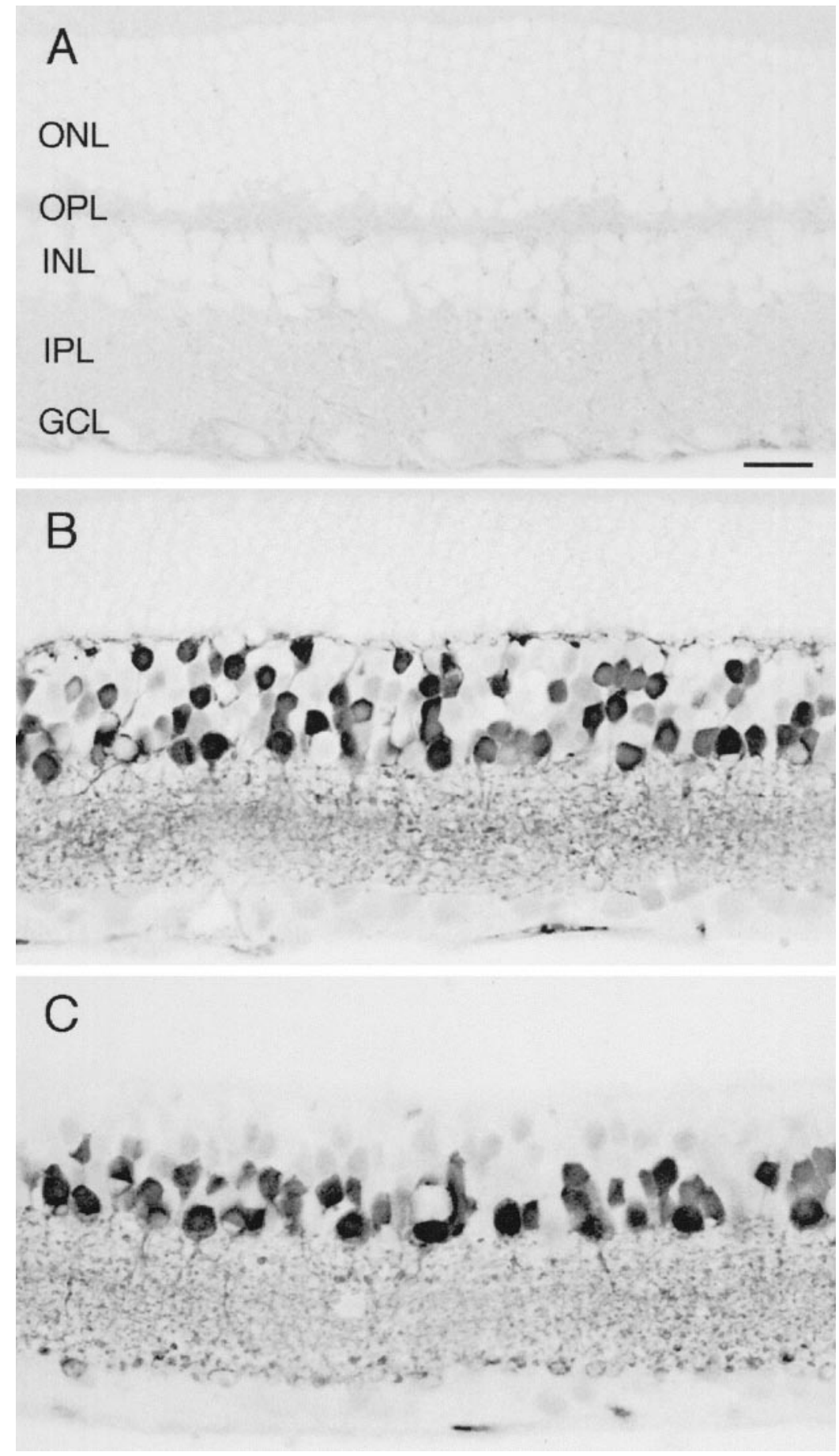

Figure 4. Replenishment of endogenous glycine in coupled and uncoupled retinas. Negative confocal micrographs of glycine immunofluorescence in transverse vibratome sections of the rat retina. $A$, Incubation of the retina with sarcosine for $4 \mathrm{~h}$ depletes the endogenous glycine in both the amacrine cells and the bipolar cells. $B$, Subsequent incubation of the retina in control medium for $2 \mathrm{~h}$ replenishes the glycine stores in both the amacrine cells and the bipolar cells. $C$, Incubation of the retina with sarcosine for $3 \mathrm{~h}$, then with sarcosine and carbenoxolone for $1 \mathrm{~h}$, and subsequently with carbenoxolone alone for $2 \mathrm{~h}$, blocks the glycine replenishment of the bipolar cells but not the amacrine cells. (In central rat retina, the amacrine sublayer of the inner nuclear layer is several cells thick.) Scale bar, $20 \mu \mathrm{m}$. spaced somata are typically larger and more immunofluorescent than the well coupled bipolar cells, suggesting that they mostly comprise a single cell type. Indeed, the glycineimmunofluorescence of these bipolar cells was $\sim 20 \%$ greater than that of the overlying AII amacrine cells (after subtracting the background fluorescence), raising doubts about whether the AII amacrine cells could be the source of the glycine in these bipolar cells (see Discussion). The array of green bipolar cells may also include one or more types that are present at very low density, such as the type $b$ wide-field bipolar cells (Famiglietti, 1981; Jeon and Masland, 1995); the homologous CBb5 cells in the cat retina reportedly do not make gap junctions with AII amacrine cells (Cohen and Sterling, 1990).
The AII cells account for $11 \%$ of all amacrine cells in the rabbit retina (Vaney et al., 1991), and the ratio of amacrine cells to cone bipolar cells is $\sim 100: 96$ in superior retina (Strettoi and Masland, 1995). Given these figures, it is estimated that the illustrated field should contain 130 cone bipolar cells, comprising about equal numbers of $\mathrm{CB} a$ and $\mathrm{CB} b$ cells. There were actually 67 glycineimmunopositive bipolar cells present in the field, thus supporting their identity with the CB $b$ cells (Cohen and Sterling, 1986). The topographic distributions of several types of cone bipolar cells have been mapped in the rabbit retina (Mills and Massey, 1992; Massey and Mills, 1996), and the peripheral densities of each type almost match those of the AII amacrine cells (Vaney et al., 1991). The glycine-immunopositive cone bipolar cells were present at 
Amacrine Cells
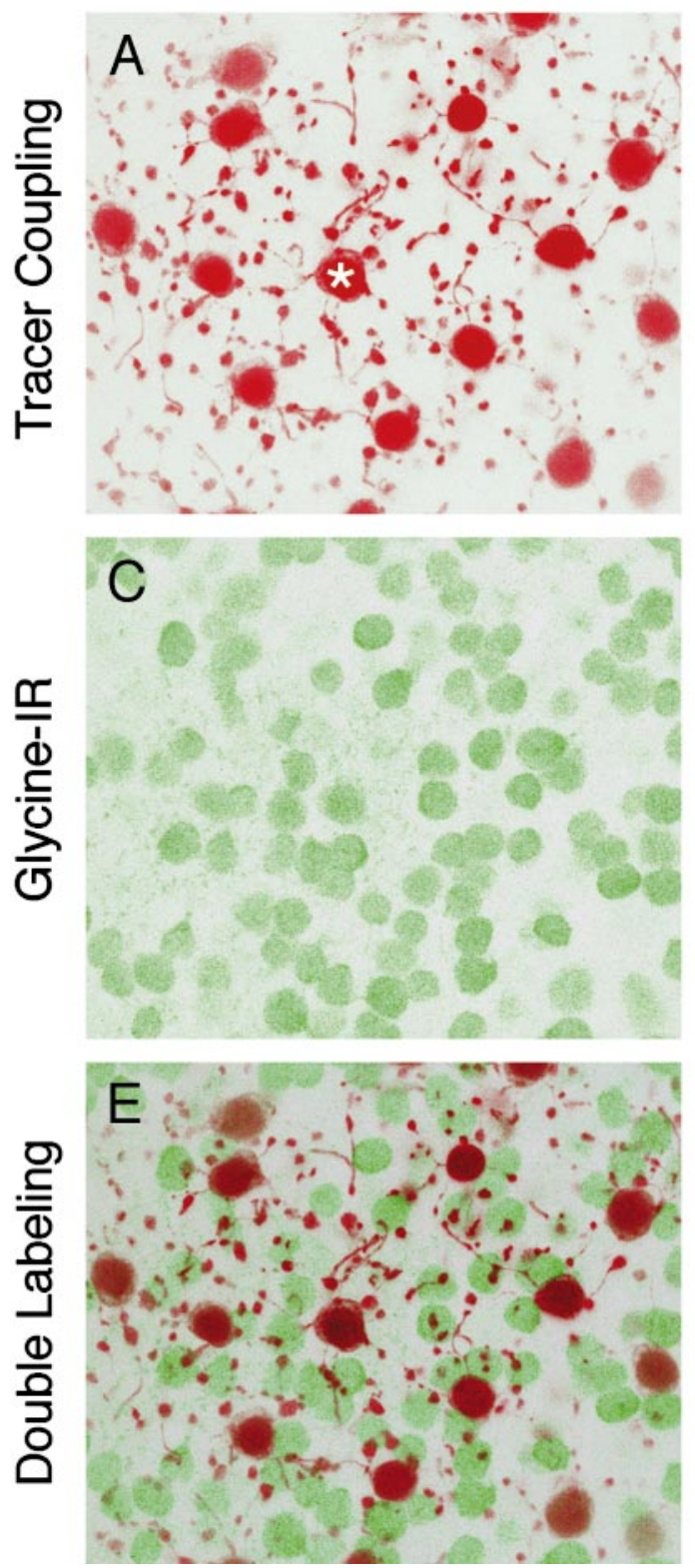

Bipolar Cells
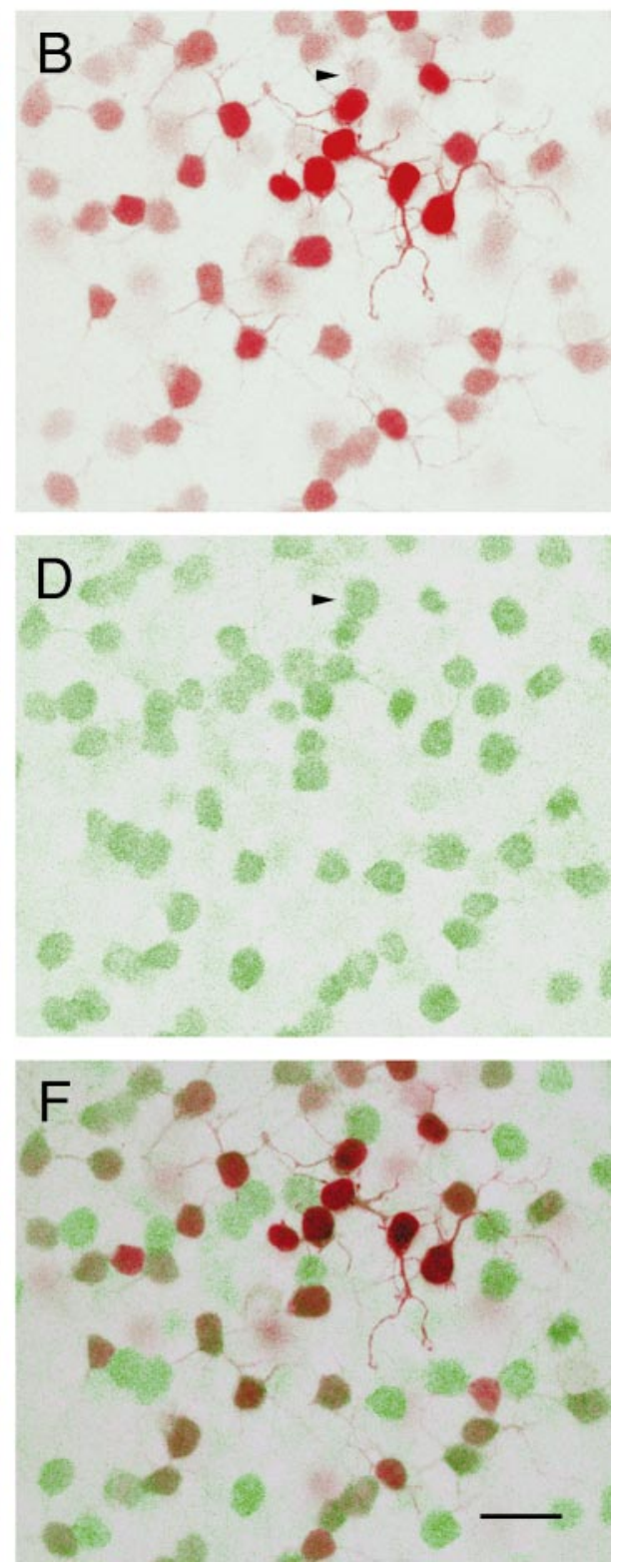

Figure 5. Tracer-coupled bipolar cells contain elevated levels of endogenous glycine. Negative confocal micrographs of a rabbit retinal whole mount doublelabeled for Neurobiotin histofluorescence (Texas Red) and glycine immunofluorescence (FITC). Neurobiotin injection of an AII amacrine cell (asterisk) results in tracer coupling of $(A)$ neighboring AII cells (somata and lobular appendages illustrated) and $(B)$ underlying cone bipolar cells (somata and dendrites illustrated). Comparison with the arrays of glycine-immunoreactive somata reveals that $(C)$ the AII cells account for $\sim 15 \%$ of the glycineimmunopositive amacrine cells, and $(D)$ most of the tracer-coupled bipolar cells are glycine immunopositive, including those that are only weakly coupled (arrowhead). E, $F$, The double-labeled AII amacrine cells and cone bipolar cells appear brown in the combined micrographs. Scale bar, $20 \mu \mathrm{m}$.
$4.5 \times$ the density of the AII cells, and, therefore they may comprise four or five common types. The glycine-immunopositive cells that showed weak tracer coupling in the rabbit retina may be homologous to the $\mathrm{CB} b 3$ cells in the cat retina. These cells do not make gap junctions with the AII amacrine cells directly but rather are coupled indirectly through the $\mathrm{CB} b 4$ cells.

\section{DISCUSSION}

This study demonstrates that the elevated levels of glycine in some types of cone bipolar cells probably arise by metabolic coupling through gap junctions with glycinergic amacrine cells, rather than by direct uptake or synthesis. Both the uptake of exogenous glycine and the replenishment of endogenous glycine in the cone bipolar cells were dramatically reduced when the gap junctions were blocked with carbenoxolone. This is consistent with the finding that the high-affinity glycine transporter GLYT1 was expressed by the glycinergic amacrine cells but not by the bipolar cells.
Although the double-label experiments provide qualitative support for the original hypothesis that the AII amacrine cells are the source of the glycine (Cohen and Sterling, 1986; Marc, 1989), it is necessary to reconcile the finding that the cone bipolar cells that showed the strongest glycine-immunofluorescence also showed the weakest tracer coupling; indeed, the glycine levels in these bipolar cells may exceed those in the AII amacrine cells, as reported in other species (Pourcho and Goebel, 1987a; Kalloniatis et al., 1996). The relative levels of a gap junction-permeant metabolite in heterologously coupled cells will be determined by a complex range of factors, including the modes of synthesis, uptake, storage, release, and catabolism in each cell type, as well as the bidirectional permeability of the gap junctions over time (for review, see Marc, 1989). A number of distinct scenarios could lead to a situation in which the overall concentration of the metabolite was lower in the source cell than in the sink cell. For example, if a type of cone bipolar cell was only weakly coupled to 
the AII amacrine cells, as shown in this study, this may lead to long equilibration times after fluctuations in the glycine levels of the AII cells, which may be naturally occurring or experimentally induced (Wright et al., 1997). Alternatively, other types of glycinergic amacrine cells may be the source of the elevated glycine in some cone bipolar cells. In the cat retina, the $\mathrm{CB} b$ cells also make gap junctions with the A8 amacrine cells (Kolb and Nelson, 1996), which strongly accumulate ${ }^{3} \mathrm{H}$-glycine (Pourcho and Goebel, 1985), but homologous amacrine cells have yet to be identified in the rabbit retina.

The question still arises whether the concentration of free glycine in the cytoplasm of the amacrine cells would be sufficient to account for the elevated levels of glycine in the $\mathrm{CB} b$ cells, given that the vesicular glycine transporter would concentrate the cytoplasmic glycine within the synaptic vesicles of the amacrine cells, forming a nondiff usible pool. The plasma membrane glycine transporter GLYT1 is distributed all around the glycinergic amacrine cells, and the intracellular concentration of free glycine should be maximal at the cytoplasmic surface of the plasma membrane. Moreover, the AII amacrine cells show stronger GLTY1-immunofluorescence than most other types of glycinergic amacrine cells, raising the possibility that the concentration of free glycine near their gap junctions is much higher than indicated by the moderate levels of glycine-immunofluorescence in the cytoplasm of fixed cells.

Converging physiological and pharmacological evidence indicates that all types of $\mathrm{CB} b$ cells are depolarized by light and provide an excitatory glutamatergic input to the depolarizing ganglion cells, which stratify in sublamina $b$ of the inner plexiform layer. This contrasts with an earlier hypothesis (Sterling, 1983) that the $\mathrm{CB} b 2$ cells in the cat retina are hyperpolarized by light and provide an inhibitory glycinergic input to the ganglion cells. Three subsequent findings undermined this "push-pull" hypothesis. First, most $\mathrm{CB} b$ cells appear to contain elevated levels of glycine, thus providing no basis for distinguishing excitatory and inhibitory cell types (Cohen and Sterling, 1986). Second, the $\mathrm{CB} b 2$ cells make sign-conserving electrical synapses with the AII amacrine cells, which are depolarized by light (Cohen and Sterling, 1990). Third, the output ribbon synapses of cone bipolar cells are not immunoreactive for the $\alpha 1$ subunit of the glycine receptor (Sassoè-Pognetto et al., 1994). Although there is little evidence that the glycine in the cone bipolar cells is used as an inhibitory transmitter, it is possible that the glycine potentiates the NMDA component of the excitatory glutamatergic responses (Johnson and Ascher, 1987). NMDA receptors have been localized at the ribbon synapses of both $\mathrm{CB} a$ and $\mathrm{CB} b$ cells (Hartveit et al., 1994), and there is no compelling argument for why the NMDA response should be potentiated in only the $\mathrm{CB} b$ cells.

Although the elevated levels of glycine in some types of cone bipolar cells may prove to have a specific function, this study indicates that they are an epiphenomenon of electrical coupling between neurons that use different neurotransmitters. Thus transmitter content may be an unreliable indicator of transmitter function for neurons that make heterologous gap junctions.

\section{REFERENCES}

Blasberg R, Lajtha A (1966) Heterogeneity of the mediated transport systems of amino acid uptake in brain. Brain Res 1:86-104.

Brehm P, Lechleiter J, Smith S, Dunlap K (1989) Intercellular signaling as visualized by endogenous calcium-dependent bioluminescence. Neuron 3:191-198.

Brissette JL, Kumar NM, Gilula NB, Hall JE, Dotto GP (1994) Switch in gap junction protein expression is associated with selective changes in junctional permeability during keratinocyte differentiation. Proc Natl Acad Sci USA 91:6453-6457.

Cohen E, Sterling P (1986) Accumulation of $\left({ }^{3} \mathrm{H}\right)$ glycine by cone bipolar neurons in the cat retina. J Comp Neurol 250:1-7.

Cohen E, Sterling P (1990) Demonstration of cell types among cone bipolar neurons of cat retina. Philos Trans R Soc Lond B Biol Sci 330:305-321.

Daley EC (1990) The biochemistry of glycinergic neurons. In: Glycine neurotransmission (Ottersen OP, Storm-Mathisen J, eds), pp 25-66. New York: Wiley.

Davidson JS, Baumgarten IM (1988) Glycyrrhetinic acid derivatives: a novel class of inhibitors of gap-junctional intercellular communication: structure-activity relationships. J Pharmacol Exp Ther 246:1104-1107.

Ehinger B, Falck B (1971) Autoradiography of some suspected neurotransmitter substances: GABA glycine, glutamic acid, histamine, dopamine, and L-dopa. Brain Res 33:157-172.

Famiglietti EJ (1981) Functional architecture of cone bipolar cells in mammalian retina. Vision Res 21:1559-1563.

Finbow ME, Pitts JD (1981) Permeability of junctions between animal cells. Exp Cell Res 131:1-13.

Guan X, Wilson S, Schlender KK, Ruch RJ (1996) Gap-junction disassembly and connexin 43 dephosphorylation induced by $18 \beta$ glycyrrhetinic acid. Mol Carcinog 16:157-164.

Guastella J, Brecha N, Weigmann C, Lester HA, Davidson N (1992) Cloning, expression, and localization of a rat brain high-affinity glycine transporter. Proc Natl Acad Sci USA 89:7189-7193.

Hampson EC, Vaney DI, Weiler R (1992) Dopaminergic modulation of gap junction permeability between amacrine cells in mammalian retina. J Neurosci 12:4911-4922.

Hartveit E, Brandstatter JH, Sassoè-Pognetto M, Laurie DJ, Seeburg PH, Wässle H (1994) Localization and developmental expression of the NMDA receptor subunit NR2A in the mammalian retina. J Comp Neurol 348:570-582.

Hendrickson AE, Koontz MA, Pourcho RG, Sarthy PV, Goebel DJ (1988) Localization of glycine-containing neurons in the Macaca monkey retina. J Comp Neurol 273:473-487.

Jeon CJ, Masland RH (1995) A population of wide-field bipolar cells in the rabbit's retina. J Comp Neurol 360:403-412.

Johnson JW, Ascher P (1987) Glycine potentiates the NMDA response in cultured mouse brain neurons. Nature 325:529-531.

Kalloniatis M, Marc RE, Murry RF (1996) Amino acid signatures in the primate retina. J Neurosci 16:6807-6829.

Kandler K, Katz LC (1998) Coordination of neuronal activity in developing visual cortex by gap junction-mediated biochemical communication. J Neurosci 18:1419-1427.

Kolb H, Famiglietti EV (1974) Rod and cone pathways in the inner plexiform layer of cat retina. Science 186:47-49.

Kolb H, Nelson R (1996) Hyperpolarizing, small-field, amacrine cells in cone pathways of cat retina. J Comp Neurol 371:415-436.

Liu QR, Lopez-Corcuera B, Mandiyan S, Nelson H, Nelson N (1993) Cloning and expression of a spinal cord- and brain-specific glycine transporter with novel structural features. J Biol Chem 286:2280222808.

Marc RE (1984) The role of glycine in retinal circuitry. In: Retinal transmitters and modulators: models for the brain (Morgan WW, ed), pp 119-158. Florida: CRC.

Marc RE (1989) The role of glycine in the mammalian retina. Prog Retinal Res 8:67-107.

Massey SC (1990) Cell types using glutamate as a neurotransmitter in the vertebrate retina. Prog Retinal Res 9:399-425.

Massey SC, Mills SL (1996) A calbindin-immunoreactive cone bipolar cell type in the rabbit retina. J Comp Neurol 366:15-33.

Mills SL, Massey SC (1992) Morphology of bipolar cells labeled by DAPI in the rabbit retina. J Comp Neurol 321:133-149.

Mills SL, Massey SC (1995) Differential properties of two gap junctional pathways made by AII amacrine cells. Nature 377:734-737.

Müller F, Wässle H, Voigt T (1988) Pharmacological modulation of the rod pathway in the cat retina. J Neurophysiol 59:1657-1672.

Osborne PB, Williams JT (1996) Forskolin enhancement of opioid currents in rat locus coeruleus neurons. J Neurophysiol 76:1559-1565.

Pourcho RG, Goebel DJ (1985) A combined Golgi and autoradiographic study of $\left({ }^{3} \mathrm{H}\right)$ glycine-accumulating amacrine cells in the cat retina. J Comp Neurol 233:473-480.

Pourcho RG, Goebel DJ (1987a) A combined Golgi and autoradio- 
graphic study of ${ }^{3} \mathrm{H}$-glycine-accumulating cone bipolar cells in the cat retina. J Neurosci 7:1178-1188.

Pourcho RG, Goebel DJ (1987b) Visualization of endogenous glycine in cat retina: an immunocytochemical study with Fab fragments. J Neurosci 7:1189-1197.

Pourcho RG, Goebel DJ (1990) Autoradiographic and immunocytochemical studies of glycine-containing neurons in the retina. In: Glycine neurotransmission (Ottersen OP, Storm-Mathisen J, eds), pp 355-389. New York: Wiley.

Pow DV (1998) Transport is the primary determinant of glycine content in retinal neurons. J Neurochem 70:2628-2636.

Pow DV, Crook DK (1993) Extremely high titre polyclonal antisera against small neurotransmitter molecules: rapid production, characterisation and use in light- and electron-microscopic immunocytochemistry. J Neurosci Methods 48:51-63.

Pow DV, Vaney DI (1998) Blockade of glycine transport depletes retinal neurons of glycine and reveals a glycine-accumulating system in rabbit cholinergic amacrine cells. Invest Ophthalmol Vis Sci 39:S686.

Pow DV, Wright LL, Vaney DI (1995) The immunocytochemical detection of amino-acid neurotransmitters in paraformaldehyde-fixed tissues. J Neurosci Methods 56:115-123.

Rieske E, Schubert P, Kreutzberg GW (1975) Transfer of radioactive material between electrically coupled neurons of the leech central nervous system. Brain Res 84:365-382.

Sáez JC, Connor JA, Spray DC, Bennett MVL (1989) Hepatocyte gap junctions are permeable to the second messenger, inositol 1,4,5triphosphate, and to calcium ions. Proc Natl Acad Sci USA 86:2708-2712.
Sassoè-Pognetto M, Wässle H, Grünert U (1994) Glycinergic synapses in the rod pathway of the rat retina: cone bipolar cells express the $\alpha 1$ subunit of the glycine receptor. J Neurosci 14:5131-5146.

Spray DC (1996) Physiological properties of gap junction channels in the nervous system. In: Gap junctions in the nervous system (Spray DC, Dermietzel R, eds), pp 39-59. Austin: RG Landes.

Sterling P (1983) Microcircuitry of the cat retina. Annu Rev Neurosci 6:149-185.

Strettoi E, Masland RH (1995) The organization of the inner nuclear layer of the rabbit retina. J Neurosci 875-888.

Tsien RW, Weingart R (1976) Inotropic effect of cyclic AMP in calf ventricular muscle studied by a cut end method. J Physiol (Lond) 260:117-141.

Vaney DI (1991) Many diverse types of retinal neurons show tracer coupling when injected with biocytin or Neurobiotin. Neurosci Lett 125:187-190.

Vaney DI (1994) Patterns of neuronal coupling in the retina. Prog Retinal Eye Res 13:301-355.

Vaney DI (1997) Neuronal coupling in rod-signal pathways of the retina. Invest Ophthalmol Vis Sci 38:267-273.

Vaney DI, Gynther IC, Young HM (1991) Rod-signal interneurons in the rabbit retina: 2. AII amacrine cells. J Comp Neurol 310:154-169.

Wright LL, Macqueen CL, Elston GN, Young HM, Pow DV, Vaney DI (1997) The DAPI-3 amacrine cells of the rabbit retina. Vis Neurosci 14:473-492.

Zafra F, Aragón C, Olivares L, Danbolt NC, Giménez C, Storm-Mathisen J (1995) Glycine transporters are differentially expressed among CNS cells. J Neurosci 15:3952-3969. 